\title{
The Relational Nature of Employment Dualization: Evidence from Subcontracting Establishments
}

\author{
Fabian Ochsenfeld \\ Friedrich-Alexander-Universität Erlangen-Nürnberg \\ Chair for Empirical Economic Sociology \\ Findelgasse 7/9, 90402 Nürnberg, Germany \\ Working Paper / Preprint \\ Accepted for publication in \\ European Sociological Review \\ https://doi.org/10.1093/esr/icy013 \\ Published by Oxford University Press
}

\begin{abstract}
Scholars argue that the dual path to labor market flexibility protects the privileges of core workers at the expense of employees relegated to a peripheral employment sector. Yet whether core workers indeed benefit from workforce segmentation remains disputed. To scrutinize this question, I study how the wages of core workers with less than college education respond when their employer shifts employment out to subcontractors, using linked employer-employee panel data from Germany. Empirically, I find the effect of subcontracting on average to be either positive or neutral, but not negative. The presence and strength of the positive effect depends, first, on whether the type of subcontracting affords core workers with codetermination rights, second, on whether core workers are represented by a works council to exercise these rights, and, third, on whether these rights are exercised in a context that augments the bargaining position of core workers by rendering conflictual labor relations costly to the employer.
\end{abstract}




\section{Introduction: Subcontracting, employment dualization and rising wage inequality in Germany}

With the erosion of the institutions that coordinated economic production during the postwar decades, firms face a growing need for flexibility (Piore and Sabel, 1984). They responded by loosening the employment relationship, transforming careers into jobs (Kalleberg, 2011; Weil, 2014). Governments have played a crucial role in labor market liberalization. Whereas industrial relations institutions generally declined in the U.S. and U.K., deregulation in Western European corporatist welfare states was selective and targeted at labor market entrants or a limited low-skill segment (DiPrete et al., 2006; Barbieri, 2009; Gebel and Giesecke, 2011). In Germany, political reforms created and expanded forms of employment with scant employment protection and secondary types of welfare provision, but because the standard employment contract with high dismissal protection, access to internal labor markets, and health and unemployment insurance benefits was preserved with relatively few modifications, Germany's path to flexibility can be characterized as one of dualization (Eichhorst and Marx, 2011; Emmenegger, 2014; Thelen, 2014).

Dualization is thought to be a relational process. The creation of disprivileged secondary employment types supposedly preserves the privileged status of core workers (Rueda, 2005; Thelen, 2014). Dualization would thus create inequality between insiders and outsiders on the basis of exploitation, in the analytical sense of the term (Sørensen, 2000): The fissuring of the workforce into types of employment with unequal social rights produces antagonistic interests insofar as the positional rents of core workers accrue because outsiders are relegated to contingent positions. Sociological and economic theories of dual labor markets claim that, indeed, they do (Solow, 1985; Lindbeck and Snower, 1986; Sørensen, 2000).

But although the dualization narrative hinges on this insider-outsider-antagonism (Rueda, 2005), we currently do not know whether core workers in fact benefit from the creation of a contingent workforce. Whereas some observers suggest that contingent workers indeed stabilize wages in the core as they are "not allowed to compete with the core sector" (Palier and Thelen, 2010: 122), others contend that "standard and nonstandard workers compete with each other for jobs" (Eichhorst and Marx, 2011: 75f.) so that core workers react to the creation of a contingent workforce "with wage moderation and other instruments strengthening their competitiveness relative to flexible workers" (Ibid.). In this paper, I scrutinize these competing claims by studying how rents of core workers respond when their employer externalizes part of the workforce, using linked employer-employee panel data which allow me to account for potentially unobserved 
confounders both at the establishment and industry level. Because wages in the data are censored, I restrict the analysis to employees with less than college education. One would have to make potentially strong additional assumptions to extrapolate from the results presented here to effects on college-educated workers.

Employment dualization in Germany coincides with rising wage inequality (Dustmann et al., 2009). Recent studies show that during the 1990s and 2000s the sorting of highwage workers into high-wage firms and of low-wage workers into low-wage employers has tightened significantly (Groß, 2012; Card et al., 2013; Ohlert, 2016, TomaskovicDevey et al., 2016). This bifurcation of 'good jobs' and 'bad jobs' explains a sizeable share of the increase in overall wage inequality (Ibid.). It was partly driven by firms outsourcing work to a low-wage service sector by way of subcontracting (Goldschmidt and Schmieder, 2017) and other ways by which work processes which used to reside in a single firm become dispersed across multiple organizations (vertical disintegration). To understand the relational nature of this large-scale redrawing of organizational boundaries, I study the feedback effect on core workers' rents for three types of subcontracting that vary in the extent of codetermination rights afforded to core workers: (1) subcontracting to temping agencies, (2) subcontracting to freelancers, and (3) the outsourcing of a business unit.

\section{The Feedback effect of subcontracting: mechanisms and competing views}

Employment dualization by way of subcontracting was facilitated by a series of labor market reforms targeted at outsiders. Between 1985 and 2005 German governments incrementally relaxed limitations on employers' use of non-standard employment relationships. This led to a strong growth in their number, especially during the $2000 \mathrm{~s}$. Agency work was deregulated in a sequence of extensions of the maximum length of assignments growing the sector continuously, yet modestly, before the limit on the duration of assignments was eventually lifted entirely in 2003 (Eichhorst and Marx, 2011; Emmenegger, 2014: Ch. 5). Thereafter, the abolishment of a regulation that had banned temping agencies from synchronizing the duration of employment contracts with the length of assignments boosted agency work (Promberger, 2012).

During the 2000s, firms also intensified their use of service contracts with self-employed freelancers (Werkverträge and Dienstverträge) to improve their flexibility or to cut costs. Although this trend is not equally well documented, research suggests that this distinct form of subcontracting acts as another driver of vertical disintegration and workforce segmentation (Hertwig et al., 2015). Figure 1 confirms the increase in both agency and 
freelance work for the study period, 2002-2008, particularly for agency work in capitalintensive industries (manufacturing, mining, utilities).

Figure 1: Agency and freelance workers as percentage of establishments' total workforce, 2002-2008.

Manufacturing, mining, utilities

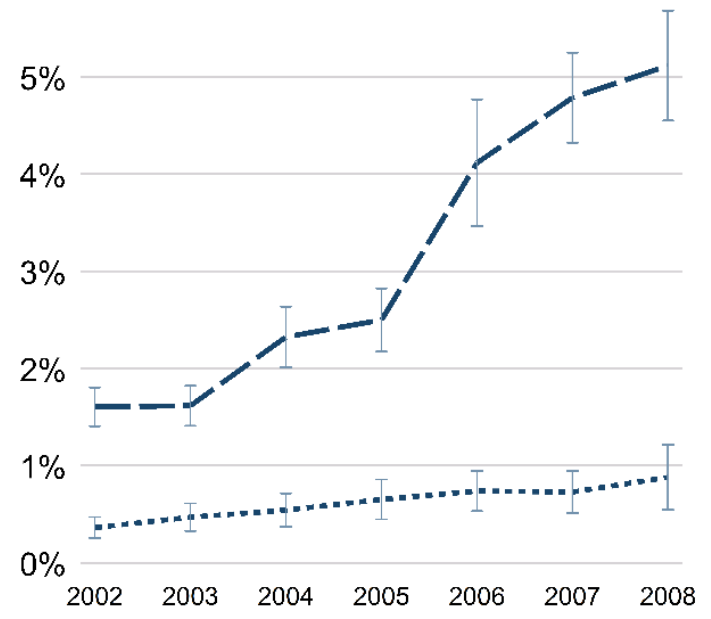

Other industries

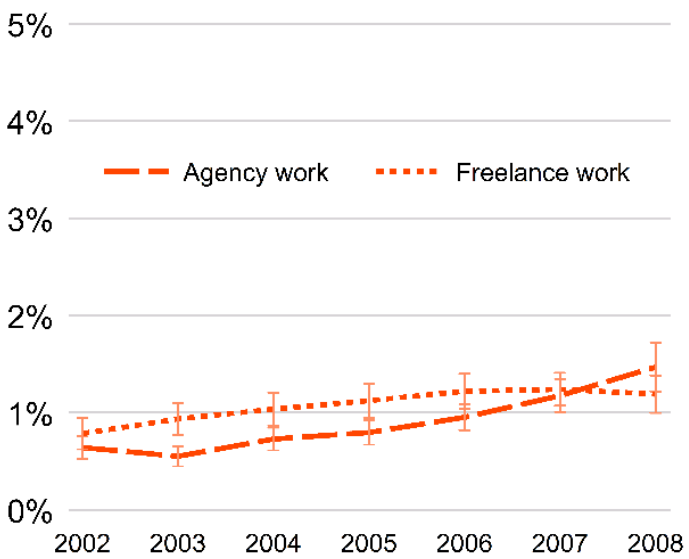

Source: IAB Establishment Panel.

Note: Private sector, for-profit establishments. Design- and size-weighted estimates.

In parallel to employment deregulation, the binding character of Germany's collective bargaining regime deteriorated in the two decades following reunification. Notably in large manufacturing firms, intensified plant-level coordination partly replaced industrylevel coordination (Streeck, 2009). Plant-level management-labor pacts codify employer commitments for future investment, training, and employment guarantees for core workers (Rehder, 2003). In turn, pacts are regularly accompanied with work council consent for cost-cutting measures such as outsourcing peripheral work tasks to low-cost service providers (Hassel, 2014).

Less skilled workers were relegated to the evolving secondary labor market with scant opportunities for rent extraction in disproportionate numbers (Gebel and Giesecke, 2011). This suggests that the well documented rising skill premium in the German labor market has partly been a consequence of selective rent destruction (Morgan and Tang, 2007; Groß, 2012; Dencker and Fang, 2016). However, evidence that the creation of a peripheral workforce through subcontracting buffers wages in the core would imply that 
employment dualization were an instance of rent redistribution (Weeden and Grusky, 2014; i.e. exploitation [Sørensen, 2000]) in which core workers appropriate rents that externalized workers lose, and not just selective rent destruction. Although this coreperiphery antagonism undergirds the dualization narrative (Rueda, 2005), it remains a matter of dispute whether core workers indeed benefit from employment dualization through vertical disintegration.

The consequences of contingent employment are well documented for those holding these positions. Compared with standard employment, contingent work is characterized by reduced job security (Giesecke, 2009), lower wages (Berlinski, 2008; Gebel, 2009; Dube and Kaplan, 2010; Goldschmidt and Schmieder, 2017), worse career prospects (Giesecke and Groß, 2003; Gebel, 2009), higher perceptions of social exclusion (Gundert and Hohendanner, 2014) and stronger demands for redistribution (Marx, 2014).

Research on the repercussions of contingent employment for core workers, however, is scant (but see Bentolila and Dolado, 1994; Polavieja, 2003; Maertz et al., 2010; Hohendanner, 2011; Pedulla, 2013; Ordine et al. 2017). Economic theory identifies two mechanisms by which workforce dualization potentially improves core workers' wages and one by which it can reduce their employment conditions.

When core worker representatives bargain with employers, they seek to maximize the outcome for their constituents by increasing their wages. However, they only do so to the extent that the resulting additional labor costs do not lead the employer to substantially reduce employment, since - absent a contingent workforce - these cuts would be borne out by core workers themselves (Solow, 1985).

Because contingent workers are known to be laid off first due to their lower firing costs, they change this situation. Insider representatives can now bargain more aggressively, knowing that the negative employment effects of their actions will not affect insiders (Layard et al., 2005). In the presence of a contingent workforce, employment considerations therefore only kick in at a much later point, when core workers' wage demands are so high that they exceed the capacity of the contingent workforce to buffer the negative effect on employment. The larger the size of the contingent workforce, the later this point is reached. Thus, the larger the size of the contingent workforce, the better core workers' bargaining outcome in terms of wages. This is the buffer effect (Bentolila and Dolado, 1994).

A second mechanism, the harassment effect, emphasizes that core workers can influence the costs and benefits of contingent workers for the employer by behaving cooperatively or not. Because insiders can choose to behave either way, they can 
condition their cooperation on employer concessions for higher wages. This rent is not available to core workers when no contingent workers are hired (Lindbeck and Snower, 1986). In the original formulation of the argument, insider cooperation refers to the personal and professional behavior of core workers towards newly employed contingent workers ('harassment'), but the mechanism also applies to how core workers chose to exercise the codetermination rights that apply when their employer seeks to hire agency workers, or to outsource employment. ${ }^{1}$

Whereas the buffer and harassment effects describe how the creation of a contingent workforce by subcontracting positively feeds back on core workers' wages, the discipline effect describes a negative feedback effect: When contingent workers perform similar tasks as core workers, they acquire similar skills, including firm-specific ones. Knowing that they enjoy very limited employment protection and that their firing costs are low, contingent workers are much less likely to strike than core workers. The presence of such a reserve workforce 'disciplines' core workers as it renders them more replaceable and their threat to go on strike therefore less credible. This reduces their bargaining power vis-à-vis the employer and thus their wages (Bentolila and Dolado, 1994; Layard et al., 2005).

These three mechanisms operate simultaneously so that their net effect is ambiguous. A number of qualitative case studies on subcontracting suggest that the two positive effects outweigh the negative discipline effect. In the face of cost pressures, subcontracting to temping agencies or freelancers, or outsourcing to low-cost service firms present themselves as alternatives to concessions that would directly reduce core workers' wages and working conditions (Doellgast and Greer, 2007). Although work councilors tend to generally oppose the intensive use of fringe workers - as do the unions to which most of them are affiliated - they consider the current insiders their core constituents and leverage their co-determination rights (providing them with some harassment potential) to bargain in their interest for employment guarantees and further training (which further increases dismissal costs) even when, in turn, they must consent to the hiring of contingent workers or outsourcing (Hassel, 2014). This is in line with theory which stipulates that works councils defend the interests of the current median

\footnotetext{
${ }^{1}$ Note that, in contrast to the hiring of agency workers, German core workers legally do not possess equally strong codetermination rights for the hiring of freelancers (Deutscher Gewerkschaftsbund, 2013) and outsourcing (Müller and Müller, 2000). Promberger (2012) provides numerous examples that document that works councilors are well aware of the bargaining power afforded to them by the codetermination rights they possess when their employer seeks to hire temporary agency workers.
} 
worker (Layard et al. 2005: p. 86), but not outsiders, and has been shown for the outsourcing of call center work in the retail (Holst, 2008) and telecommunications industry (Doellgast and Greer, 2007; Doellgast, 2008; Holst, 2008; Holst et al., 2008), temporary agency work in manufacturing (Holst et al., 2008; Promberger, 2012: 228ff.), subcontracting in the meat industry (Wagner and Hassel, 2016), and subcontracting to freelancers in further education (Holst et al., 2008). Evidence from a selective introduction of temporary agency work in Italy during the 1990s also supports this position (Ordine et al. 2017).

Extrapolating from these studies, the creation of a contingent workforce through subcontracting should thus exert a positive net effect on insider wages $\left(\mathrm{H}_{1}\right)$ as it amplifies insider bargaining power and permits the externalization of concessions. This should particularly be true in capital intensive industries $\left(\mathrm{H}_{2}\right)$ : capital-intensive production with high fixed capital costs to the employer amplifies the threat that insiders' non-cooperation poses to the employer. The so-called harassment effect should thus be magnified in a more capital-intensive context (Layard et al., 2005).

Some scholars, however, argue that the discipline effect of employment dualization predominates over the buffering and harassment effects and hence challenge the proposition that the net effect of a two-tier workforce on the core would be positive (Flecker, 2009; Holst, 2014; also see Bentolila and Dolado, 1994: 20; Polavieja, 2003: 506; Promberger, 2012: 232). When firms integrate their value chains with subcontractors in the process of outsourcing, they standardize business processes in a way that permits the use of external market prices as benchmarks to evaluate business units that remain internal (Flecker, 2009). Accordingly, subcontracting should thereby create competitive pressures that allow management to destroy core workers' rents. It should thus have a negative net effect on wages of core workers $\left(\mathrm{H}_{3}\right)$.

I will conduct separate analyses for establishments that belong to capital intensive industries (manufacturing, mining, utilities) and other industries to scrutinize $\mathrm{H}_{2}$ and since both the dualization literature and economic theory predict important differences between these groups of industries.

\section{Research design}

To scrutinize these expectations, the aim of the empirical analysis is to estimate the causal effects of three types of employment dualization through subcontracting $\left(D_{\mathrm{j}}\right)-$ hiring agency workers, hiring freelance workers, and outsourcing - on rents of core workers in a given establishment. 
$A T T=\left[E\left(Y_{j} \mid D_{j}=1\right)-E\left(Y_{j} \mid D_{j}=0\right)\right] \mid D_{j}=1$

The main challenge to identify these effects with observational data is potential selection of establishments into work externalization on the basis of both time-constant and timevarying characteristics which themselves affect the level of rents. I pursue a threepronged strategy to overcome this problem using (1) establishment fixed effects (FEs) to control for time-constant confounders, (2) explicit measures of time-varying establishment characteristics as one way to control for time-varying confounders and (3) cell-year FEs to additionally control for unobserved time-varying confounders in the following regression specifications:

$$
r_{j t}=\boldsymbol{\beta D}_{j t}+\boldsymbol{\omega} \boldsymbol{X}_{j t}+\alpha_{j}+\gamma_{s t}+\theta_{k l t}+\varepsilon_{j t}
$$

where $r_{j t}$ is the rent level of core workers for establishment $j$ in year $t$. $\boldsymbol{D}_{j t}$ is a vector with the three treatment variables (percentage of temporary agency workers, percentage of freelancers subcontracting to freelancers, outsourcing, plus two squared terms to allow for potential non-linearity in the effects of the former two continuous variables). Due to establishment FEs, $\alpha_{j}$, the model is estimated from longitudinal within-establishment variation only. $\gamma_{s t}$ is a vector of year-state FEs which control for time trends that are common to establishments in a given federal state.

$\boldsymbol{X}_{j t}$ is a vector of time-varying establishment characteristics that potentially confound the effects of interest (see Table A1 for an overview). I include in $\boldsymbol{X}_{j t}$, first, a firm's business situation because employers may resort to subcontracting or outsourcing to cut costs in response to a deterioration of their business situation which itself has a negative effect on rents (Card et al., 2018). Second, to control for establishment-specific employment trends, I control for the total number of employees (core and contingent workers combined, linear, squared and logged). Third, $\boldsymbol{X}_{j t}$ includes an indicator for whether an establishment currently has vacancies to fill because employers are known to use agency work to resolve a skill shortage (Promberger, 2012) which independently improves insiders' bargaining position and thus their wages. Fourth, I control for the changing export intensity of an establishment because employers that enter export markets have been shown to pay a wage premium (Schank et al., 2007), yet internationalization may also foster (or inhibit) workforce restructuring. Fifth, it is plausible that employers who experience an increase in labor costs after adopting collective bargaining (Addison et al., 2014) turn to subcontracting and outsourcing to cut costs or replace their organized workforce with contingent workers (Autor, 2003; Goldschmidt and Schmieder, 2017). 
Specification a1 follows an interpretation which considers all of these characteristics as confounders to be controlled for. However, in this longitudinal setting, each of these characteristics can plausibly be argued to mediate the effect of subcontracting on core workers' wages. Conditioning on them thus creates overcontrol bias (Elwert and Winship, 2014). Since $\boldsymbol{X}_{j t}$ are simultaneously confounders and mediators (Robins et al., 2000) and for each characteristic the direction of bias due to confounding is a priori ambiguous, I estimate across all possible combinations of these controls (Young and Holsteen, 2017). The resulting set of specifications includes both the model that most heavily under-controls and the model that most heavily over-controls. These extreme estimates can thus serve as bounds on the true effect (Tamer, 2010; Gangl, 2013) which I will report and interpret instead of point-identified estimates.

The credibility of estimates from FE models depends on the parallel trends assumption (Brüderl and Ludwig, 2015), that is, the assumption that net of $\boldsymbol{X}_{j t}$ and $\gamma_{s t}$ establishments that subcontracted - had they not subcontracted - would have followed the same rent trends as establishments that did not. The propensity to subcontract work, however, will depend on factors such as the supply of adequately skilled employees willing to take up outsourced positions or on the organizational and technical feasibility of subcontracting. Estimates would be biased if the propensity to subcontract, which is determined by these factors, was correlated with trends in rents. To avoid this bias, establishments that subcontract more should be compared with establishments that subcontract less although they had the same propensity to subcontract.

Trends in the propensity to subcontract can plausibly be argued to be similar for establishments that operate in the same industry and also have a similar size because such similar establishments are likely subject to similar changes in production technology, competitive pressure, and availability of skilled employees. I use this intuition to absorb non-parametric time trends specific to establishments in a given a given industry $k$ and a given size-category $/$ through a long vector of industry-size-year FEs, $\theta_{k l t}$. The effects of interest are thus estimated by comparing rent changes within establishments that subcontracted more to rent changes within establishments of the same industry and the same size that subcontracted less.

The (untestable) identifying assumption then is that within a given industry-size cell and net of observed variables $X_{j t}$, establishments do not select into subcontracting on the basis of unobserved time-varying establishment characteristics that themselves are systematically correlated with trends in the level of rent. 
I here conceive of firm rent as the wage component employees receive in excess of what is necessary to induce the supply of their labor (Sørensen, 1996). In line with this concept, rents are operationalized through over-time changes in the wage premium a firm pays in addition to the market price, more specifically, as the establishment residual $r_{j t}$ from the following wage regression:

(b) $\log \left(w_{i t}\right)=\boldsymbol{\delta} \boldsymbol{X}_{i t}+\zeta_{s t}+\eta_{\text {oet }}+\tau_{i j}+r_{j t}+\varepsilon_{i t}$

$\boldsymbol{X}_{i t}$ is a vector of time-varying person characteristics ${ }^{2}$, and $\zeta_{s t}$ are state-year FEs. Crucially, I also non-parametrically control for changes in the market price for skill cells to substantiate my interpretation of the establishment residual $r_{j t}$ from this equation as rent. A skill cell is the combination of 2-digit occupation, $O$, with the level of education, $e .^{3}$ I allow wages for these skill cells to vary randomly across each year of the 7-year observation period through $\eta_{\text {oet, }}$ a high dimensional vector of skill cell-year FEs. This provides a nonparametric control for over-time changes in the market price for skills which may be induced by technological change, immigration, or any other shift of skill demand and supply. Because workers may also be paid for unobserved productivityrelated traits, and over-time changes in workforce composition with respect to such traits could be correlated with subcontracting, I also include $\tau_{i j}$, a vector of spell (i.e. personestablishment match) FEs that render this a 'stayers design' (Card et al. 2018) which rules out this type of confounding.

\section{Data}

These models are fit to a linked employer-employee panel dataset (LIAB) that results from matching data from the IAB Establishment Panel, an employer panel study, with longitudinal administrative data on the full population of the surveyed establishments' employees covered by social security (Heining et al., 2014). In the following, I briefly describe how I operationalize the treatment $\left(\boldsymbol{D}_{j t}, 4.1\right)$, control $\left(\boldsymbol{X}_{j t}, 4.1\right)$, and outcome variables $\left(r_{j t}, 4.2\right)$.

\subsection{Establishment-level data}

\footnotetext{
2 These are: worker type (unskilled worker vs. skilled blue collar vs. white collar), firm-specific experience, potential general experience (linear, squared and cubed), fully interacted with gender and education (no vocational training, vocational training) to account for differences in the wage trends between establishments that are due to differences in workforce composition regarding gender, education and age/experience (see Tables A2 and A8).

${ }^{3}$ Hence, 'fine mechanics occupations with a vocational degree' is one skill cell, 'fine mechanics occupation without a vocational degree' a second cell, 'toolmaking and mold construction with a vocational degree' a third, et cetera.
} 
The IAB Establishment Panel is an annual survey of a stratified random sample of establishments that employ at least one person covered by social security (Fischer et al., 2009). I restrict the sample to private sector for-profit establishments with at least three full-time employees that are not themselves temping agencies. From 2002 onwards, the establishment panel provides consistent measures of employers' use of several types of subcontracting. To operationalize the treatments, I use proportion of temporary agency workers among the entire workforce and proportion of freelancers under service contracts as continuous measures of subcontracting as well as the outsourcing or closing of a business unit, a binary variable.

I use data for 2002-2008, the key period of employment dualization. The observation period ends in 2008 because in 2009 the German government introduced short-time work wage subsidies for crisis-ridden employers' core workforces (Crimmann et al., 2012) and this intervention strongly interferes with the research design.

For time-varying controls, I construct two measures of an establishment's business situation. First, from the self-assessment of the development of the business volume and, second, from the self-assessment of the earnings situation in the most recent completed business year. The other controls are dummy variables for whether an establishment is covered by collective bargaining and whether it currently searches for workers to be hired as soon as possible, to indicate a skill shortage. Table A1 provides an overview of the establishment-level variables.

In the rare cases of item non-response I impute linear trends for years between two complete observations. To ensure the viability of the fixed-effects approach, I split establishments by assignment of a new identifier whenever interviewers reported that they surveyed 'a different unit than last year'. In all analyses, I use weights to account for the stratified sampling design and weight establishments by their size (number of employees). A replication package documents these and all other coding decisions in full detail and is publicly and permanently available at the Harvard Dataverse (Ochsenfeld, 2018). The resulting establishment-level dataset comprises 10,546 establishments $(4,263$ in manufacturing, mining and utilities, 6,283 in the less capitalintensive industries) with on average 4 years of data. See Tables A3 and A5 for descriptive statistics.

\subsection{Employee-level data used to measure time-varying establishment rents}

Information on employees stems from the notification procedure that obliges German employers to report exact daily wages (including bonus payments) and a set of person characteristics to social security institutions (Heining et al., 2014). I restrict the sample to 
core workers: full-time social insurance covered non-apprentice employees of age 18 to 65 with a gross effective daily wage of at least $20 €^{4}$ who are with their current employer for at least two years. ${ }^{5}$

A major limitation of these data is the censoring of wages at the social security contribution ceiling. This affects 8 percent of observations for persons with less than college education. To avoid sample selection bias, I impute this information by a series of Tobit regressions with a set of establishment and employee predictors ${ }^{6}$ fit separately for Eastern and Western Germany and for each year. Among the college-educated, wages are censored in 61 percent of observations. I therefore refrain from estimation for this group. My results therefore cannot be extrapolated to the population of college educated employees, only to employees with less than college education. With respect to their qualification level, the latter will be more similar to employees that are relegated to the secondary labor market. The necessary restriction of the analysis sample to less educated employees thus stresses that rents which surviving core workers may extract in the course of vertical disintegration are positional in nature.

Missing values on other person characteristics occur almost exclusively on the education variable (in 9.1 percent of observations) which I harmonize and impute using longitudinal information from the same person (Fitzenberger et al., 2006: 415-417). The analysis sample encompasses 5,093,017 observations from 1,544,240 persons $(1,010,069$ persons in manufacturing, mining and utilities, 543,171 persons in the less capitalintensive industries). Table A4 provides descriptive statistics.

\section{Results}

The main research question of this paper is whether workforce segmentation through subcontracting augments or destroys core workers' rents. Empirically, the answer differs by type of subcontracting. In manufacturing, mining and utilities, an increase in the share of agency workers among an establishment's total workforce from zero to ten percent leads to a 1.0 to 1.3 percent wage increase for employees without a college degree (Figure 2), on average. In less capital intensive industries, this effect is also present, but weaker $(+0.6$ to +0.7 percent; Figure 2). The hiring of freelance workers has no

\footnotetext{
${ }^{4}$ Inflation-adjusted to 2010.

5 In the first 24 months of employment, workers enjoy limited dismissal protection. Therefore, I do not consider them core workers.

${ }^{6}$ Namely federal state, number of full-time employees in the establishment (logged), average wage (logged), proportion of observations censored, profit situation, employee age (squared and cubed), gender, fully interacted with experience (squared and cubed), education, fully interacted with experience (squared and cubed), nationality and industry. I top-code the extremely few imputed values above three times the value of the contribution ceiling because I consider the imputation model ill-suited for extreme outlier prediction.
} 
significant effect on core workers' wages, neither in the capital intensive, nor in the less capital intensive industries (Figures 2 and 3). Outsourcing, too, appears to consolidate core wages slightly in manufacturing, mining and utilities $(+0.4$ to +0.8 percent; Figure 2). In the less capital intensive industries, if any, outsourcing only has a weak (and not statistically significant) average effect on the wages of core workers without college education (Figure 2).

Taken together, these results suggest that workforce segmentation within establishments does not exert negative net effects on core workers. Instead, employment dualization through vertical disintegration can indeed modestly augment the wages of remaining core workers. However, and in line with theory, it appears that the presence of such a positive feedback effect depends on an institutional and organizational context in which core workers have bargaining power vis-à-vis their employer. Two observations support this interpretation.

First, we see modest positive wage effects for agency work, but not for freelance work. The law that regulates agency work in Germany grants works councils codetermination rights (§ 14, Abs. 3 Arbeitnehmerüberlassungsgesetz; § 99 Betriebsverfassungsgesetz) which can be used in bargaining to threaten the employer with "harassment" (Bentolila and Dolado, 1994): work councils can exercise their codetermination rights to delay the hiring of agency workers, and thereby interfere with management's staffing and production plans, often at a significant cost to their employer (Promberger, 2012: 232). The same codetermination rights, however, do not extend to the subcontracting of tasks to genuinely self-employed freelancers (Deutscher Gewerkschaftsbund, 2013). These two forms of subcontracting thus vary in the degree to which they improve core workers' bargaining power, and the absence of any positive effects on core workers' wages in the event of subcontracting to freelancers corresponds with the absence of strong codetermination rights for this particular type of restructuring.

Second, when employment dualization occurrs in the form of subcontracting to temporary agency workers, where core worker representatives possess codetermination rights, the opportunity to bargain translates into more positive wage effects in the more capital intensive industries. Due to higher fixed non-labor costs, the cost to of entering a conflict with labor that can delay staffing and uphold production is higher for employers in these industries, and workers' bargaining power thus bolstered in comparison with less capital intensive industries.

This interpretation of my results in the light of bargaining over rents would suggest that outcomes for core workers should be particularly positive where they are organized in a 
works council (Beckmann et al., 2010). To further probe this interpretation, I conducted further analyses that additionally allow for heterogeneity in the causal effects of subcontracting by whether or not core workers in a workplace are represented by a works council (Figure 3, Table A 6).

Even net of effect heterogeneity by establishment size, which is strongly correlated with works council status, I find that works councils indeed bolster the positive feedback effect of agency workers but only if the bargaining position of core workers is favorable due to capital intensive production: In manufacturing, mining, and utilities, an increase in the share of agency workers among an establishment's total workforce from 0 to 10 percent increases core workers' wages by about one percentage point more if the establishment has a works council, but the same is not true in the less capital intensive industries (-0.6 percentage points, not statistically significant). When an establishment hires freelancers, for which management does not need to obtain approval from the works council, being represented by a works council or not makes no large difference for core workers, irrespective of whether the industry is capital intensive $(0.0$ to +0.6 percentage points, not statistically significant $)$ or not $(+0.4$ to +0.6 percentage points, not statistically significant).

I also find the effect of outsourcing on core workers' wages to be more positive when they are represented by a works council (Figure 3) despite the fact that with respect to this type of subcontracting works councils merely posses information and consultation rights ( $\S 111$ Betriebsverfassungsgesetz) which are considerably weaker than the full codetermination rights that apply in the case of subcontracting to a temping agency (Müller and Müller, 2000). However, there are instances where an employer's effort to outsource a business unit nevertheless provides the works council with an opportunity to bargain in favor of remaining core employees (Doellgast and Greer, 2007; Doellgast, 2008). It is thus unclear whether and to what extent the observed effect heterogeneity by works council status in the case of outsourcing indeed results from the working of this mechanism. The observation that the interaction effect by works council status is pronounced in the more capital intensive industries $(+2.0$ to +2.3 percentage points) but less so in the less capital intensive industries $(+0.4$ to +0.8 percentage points) may be considered supporting evidence. However, this interpretation is not as plausible as it is in the case of temporary agency work where stronger codetermination rights apply than in the case of outsourcing. ${ }^{7}$

\footnotetext{
${ }^{7}$ Note that the reported effect sizes for average effects (Figure 2) and effect heterogeneity (Figure 3) can be directly compared between agency work and freelance work but not between these two and outsourcing. This is because the former two are continuously measured and the reported
} 
Figure 2: Effects of three types of subcontracting on gross daily wages of full-time core workers with less than college education. Estimates from three-way fixed effects models.
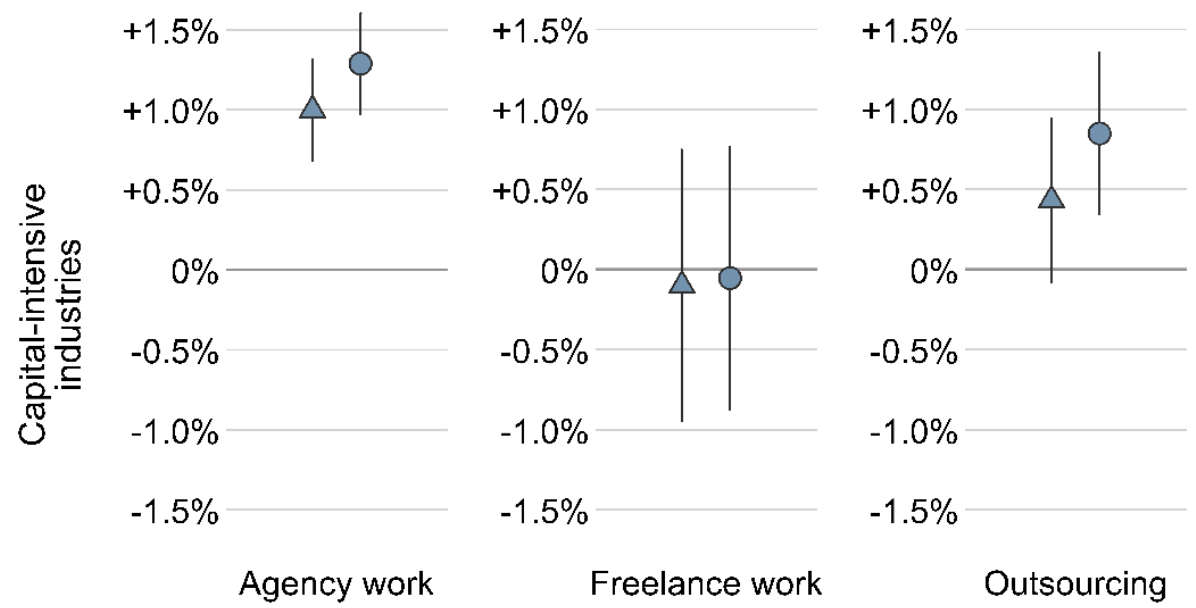

Agency work
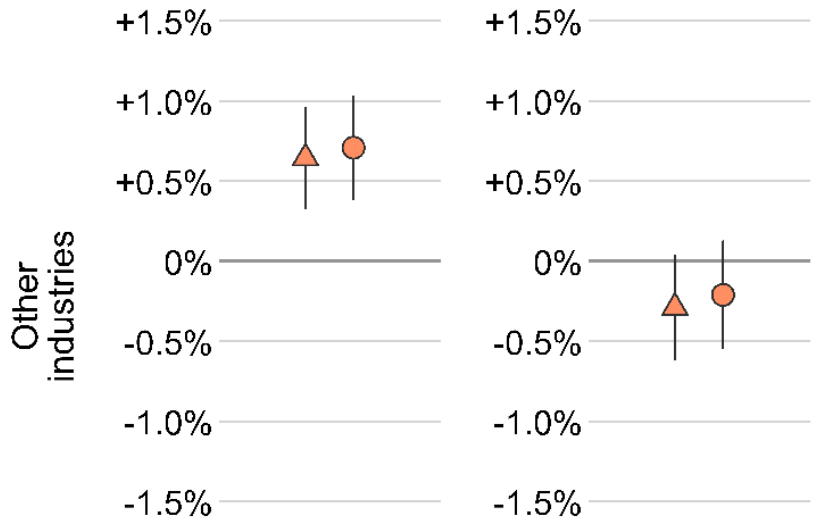

$+1.5 \%$

$+1.0 \%$

$+0.5 \%$

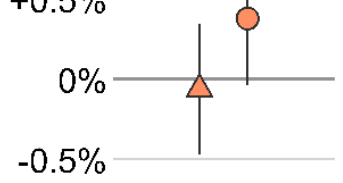

$-1.0 \%$

$-1.5 \%$

Agency work

Freelance work

Outsourcing

Legend: Triangular marker: lower bound; circular marker: upper bound. Capital-intensive industries are: manufacturing, mining, utilities. Other industries are: retail, finance, other service industries, transportation, construction, farming, fishery, and forestry. Core workers are full-time social insurance covered workers with at least two years tenure.

Notes: See Table A6 for all model parameters. Point estimates with 95-percent confidence intervals from design- and size-weighted linear regression models with establishment, state-year, and industry-size-year FEs, $N$ (establishment-years) $=18,088$ for capital-intensive industries, $\mathrm{N}=24,473$ for other industries.

Source: LIAB 2002-2008.

effects thus scaled to a fixed treatment intensity whereas those for outsourcing represent averages across heterogeneous treatment intensities since outsourcing status is measured with a binary indicator. 
Figure 3: Heterogeneity in the effects of subcontracting on gross daily wages of fulltime core workers with less than college education. Percentage point difference between the effect for an establishment with a works and an establishment without a works council.

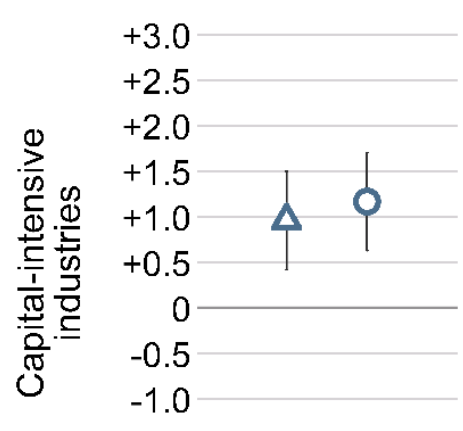

Agency work

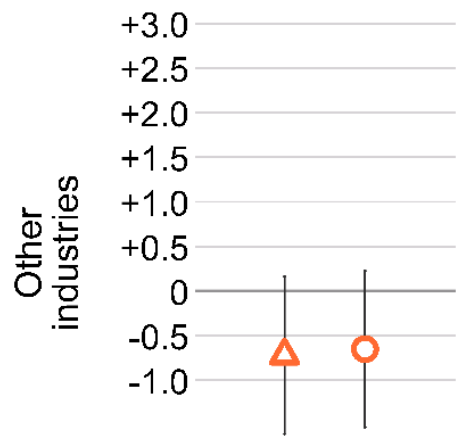

Agency work

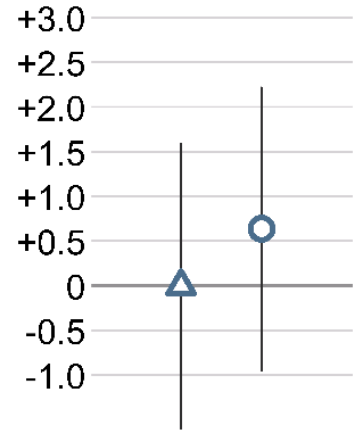

Freelance work

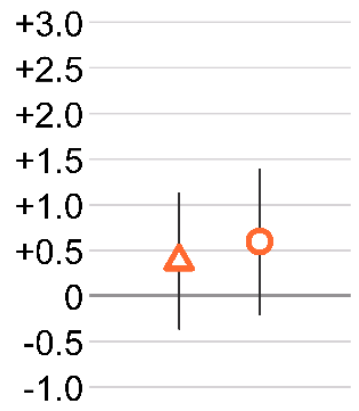

Freelance work

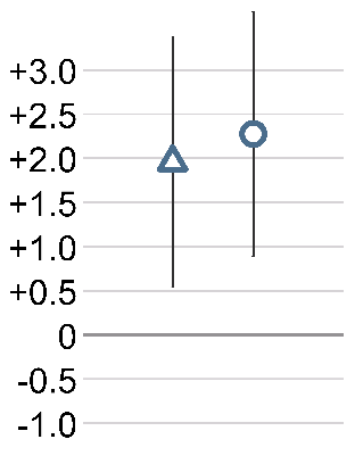

Outsourcing

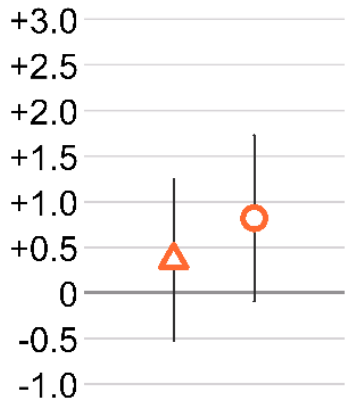

Outsourcing

Legend: Triangular marker: lower bound; circular marker: upper bound. Core workers are full-time social insurance covered workers with at least two years tenure.

Notes: Models with interactions of treatment variables with works council status and of treatment variables with seven categorical variables for establishment size. See Table A7 for all model parameters. Point estimates with 95-percent confidence intervals from design- and size-weighted linear regression models with establishment, state-year, and industry-size-cell FEs, N(establishment-years)=18,088 for capital-intensive industries, $\mathrm{N}=24,473$ for other industries.

Source: LIAB 2002-2008. 


\section{Conclusion}

Whereas most economic accounts explain rising wage inequality as resulting from a shift in the demand for types of skill, social scientists tend to emphasize the importance of country-specific political and institutional shifts that redistributed opportunities to extract labor market rents, often in ways that deepen economic disparity (Weeden and Grusky, 2014). Employment dualization, a selective and targeted approach to labor market deregulation (Thelen, 2014), potentially induced an inegalitarian redistribution of rent in continental European economies. Recent studies find that a sizeable part of rising wage inequality in Germany was due to low wage workers being increasingly excluded from firm rents.

Although scholars generally agree that corporatist continental countries differ notably from liberal market economies in their liberalization trajectories, there is no consensus yet over dualization's relational nature - whether dualization reinforces structural labor market inequality or not. Whereas some authors argue that labor market dualization has served core workers well because it protects their position from recommodification, critics argue that the gradual extension of secondary types of work creates new competitive pressures on core workers so that dualization exerts a detrimental feedback into the core.

To scrutinize these competing claims, I here drew on linked employer-employee microdata from Germany to study whether core workers economically benefit or suffer from their employer's decision to subcontract work to a peripheral workforce. Empirically, I found average effects of vertical disintegration on the wages of core workers to be either positive or neutral, but not negative. The differences in the results for subcontracting to temping agencies and freelancers suggest that whether workforce segmentation has a positive effect on core workers depends, first, on whether the type of subcontracting affords core workers with codetermination rights, second, on whether core workers are represented by a works council to exercise these rights, and, third, on whether these rights are exercised in a context that augments the bargaining position of core workers by rendering conflictual labor relations more costly to the employer. These findings were derived from data on employees with less than college education. Whether they also hold up in the population of college educated workers thus awaits corroboration from further studies.

The pattern in the effects on core workers' wages suggests that to grasp dualization's relational nature, it is insufficient to narrowly construe it as a framework that merely involves different segments of employees. To understand whether contingent forms of 
employment jeopardize or protect the position of core workers, industrial relations - the legal, economic and political conditions that structure the bargaining process between employees and employers - appear to be eminent for the creation of opportunities for standard employees to extract rents in the context of vertical disintegration. The empirical importance of codetermination rights and works councils casts doubt on interactional approaches which tend to qualify the role of such economic and legal structures by emphasizing the embeddedness of organizational inequality in local social relations (Ridgeway, 1997; Roscigno, 2011; Tomaskovic-Devey, 2014). Their salience in turn attests to a historical-institutional understanding of the interplay between organizational structure and socio-economic inequality (Kocka, 1981; Piore and Sabel, 1984; Fligstein, 1990; Thelen 2004).

Against the background of workplace fissuring and rising wage inequality, I here focused on the effect of workforce segmentation on core workers' rents. However, employment dualization may have even more significant or differently shaped feedback effects on non-pecuniary aspects of core workers' positions, such as job security or job satisfaction. Further research may extend this study to investigate the impact of subcontracting on work characteristics other than wages.

The findings presented here are based on a research design tailored to identify establishment-level effects of workforce segmentation. Compared with an industry- or country-level study, this focus has the advantage of bringing the analysis to where workforce segmentation takes place. Also, unlike industry, let alone country panels, establishment panels provide the significant amount of uncontaminated within-variation necessary to estimate the parameters of interest. However, although the establishmentlevel effects that I focused on here accumulate and thereby contribute towards the total country-level effect of dualization, at least two complications stand in the way of directly extrapolating from the establishment- to the macro-level effect of employment dualization.

First, the aggregation mechanism likely is non-trivial. My identification strategy for the establishment-level effect called for controls of economy-wide time trends and, in fact, even developments common to establishments in the same industry. This significantly bolsters the credibility of a causal interpretation of the estimates. But insofar as the total country-level effect of dualization on the divide between core and peripheral workers also entails between-industry components (Dustmann et al., 2014; Ochsenfeld, 2017), these necessarily complement the establishment-level results presented here. 
Second, my analysis was based on a conception of dualization as a form of structural inequality between groups of employees. This conventional use of the concept should not mask the fact that the institutionalization of employment dualization partly displaced labor shedding programs of the 1970s and 1980s that had implied their own forms of structural inequality between persons inside and outside the labor market. The shift from labor shedding policies to dualistic measures of activation arguably exerted a positive feedback effect on core workers since they reduced standard employees' social security contributions and income tax (Esping-Andersen, 1996; Streeck, 2009). A complete account of dualization's feedback effect on the core would have to factor this mechanism in, too.

Acknowledgements: An earlier version of this paper was presented at the RC28 Spring Meeting in Cologne, the Meeting of the Section 'Social Inequality and Social Structure Analysis' of the German Sociological Association in Tübingen and the $21^{\text {st }}$ Colloquium on Personnel Economics in Munich. I thank all participants and Jan Brülle, Markus Gangl, Rona Geffen, Andreas Haupt for helpful comments. This study uses LinkedEmployer-Employee Data (LIAB QM2 9310) from the IAB. Data access was provided via on-site use at the Research Data Centre (FDZ) of the German Federal Employment Agency (BA) at the Institute for Employment Research and subsequently remote data access. Thanks to Sergio Correia for -reghdfe- (Correia, 2017).

Funding: This work was supported by Priority Program 1764 of the German Science Foundation (DFG), project GA 758/4-1 Organizational Structure, Technological Change and Rising Wage Inequality in Germany: An Empirical Study Using Linked-EmployerEmployee Data. 


\section{References}

Addison, J., Teixeira, P., Evers, K., \& Bellmann, L. (2014). Indicative and Updated Estimates of the Collective Bargaining Premium in Germany. Industrial Relations, 53, 125-156.

Autor, D. (2003). Outsourcing at Will: The Contribution of Unjust Dismissal Doctrine to the Growth of Employment Outsourcing. Journal of Labor Economics, 21, 1-42.

Barbieri, P. (2009). Flexible Employment and Inequality in Europe. European Sociological Review, 25, 621-628.

Beckmann, M., Föhr, S., \& Kräkel, M. (2010). Rent Seeking, Employment Security, and Works Councils: Theory and Evidence from Germany. Schmalenbach Business Review, 62, 2-40.

Bentolila, S., \& Dolado, J. (1994). Labour flexibility and wages: lessons from Spain. Economic Policy, 9, 55-99.

Berlinski, S. (2008). Wages and Contracting Out: Does the Law of One Price Hold? British Journal of Industrial Relations, 46, 59-75.

Brüderl, J., \& Ludwig, V. (2015). Fixed-effects panel regression. In H. Best \& C. Wolf (Eds.), The SAGE Handbook of Regression Analysis and Causal Inference (pp. 327-357). London: Sage.

Card, D., Cardoso, A., Heining, J., \& Kline, P. (2018). Firms and Labor Market Inequality: Evidence and Some Theory. Journal of Labor Economics, 36, S13-S70.

Card, D., Heining, J., \& Kline, P. (2013). Workplace Heterogeneity and the Rise of West German Wage Inequality. The Quarterly Journal of Economics, 128, 967-1015.

Correia, S. (2017). reghdfe: Stata module for linear and instrumental-variable/GMM regression absorbing multiple levels fixed effects. Statistical Software Components, Boston College Department of Economics. https://ideas.repec.org/c/boc/bocode/s457874.html

Crimmann, A., Wießner, F., \& Bellmann, L. (2012). Resisting the crisis: short-time work in Germany. International Journal of Manpower, 33, 877-900.

Dencker, J., \& Fang, C. (2016). Rent Seeking and the Transformation of Employment Relationships: The Effect of Corporate Restructuring on Wage Patterns, Determinants, and Inequality. American Sociological Review, 81, 467-487.

Deutscher Gewerkschaftsbund (2013). Betriebsrat und Werkverträge. Mitbestimmung beim Einsatz von WerkverträglerInnen. http://www.dgb.de/themen/++co++191204d8-3281-11e38364-00188b4dc422

DiPrete, T., Goux, D., Maurin, E., \& Quesnel-Vallee, A. (2006). Work and pay in flexible and regulated labor markets: A generalized perspective on institutional evolution and inequality trends in Europe and the U.S. Research in Social Stratification and Mobility, 24, 311-332.

Doellgast, V. (2008). National Industrial Relations and Local Bargaining Power in the US and German Telecommunications Industries. European Journal of Industrial Relations, 14, 265 287.

Doellgast, V., \& Greer, I. (2007). Vertical Disintegration and the Disorganization of German Industrial Relations. British Journal of Industrial Relations, 45, 55-76.

Dube, A., \& Kaplan, E. (2010). Does outsourcing reduce wages in the low-wage service occupations? Evidence from janitors and guards. ILR Review, 63, 287-306.

Dustmann, C., Ludsteck, J., \& Schönberg, U. (2009). Revisiting the German Wage Structure. The Quarterly Journal of Economics, 124, 843-881.

Dustmann, C., Fitzenberger, B., Schönberg, U., \& Spitz-Oener, A. (2014). From Sick Man of Europe to Economic Superstar: Germany's Resurgent Economy. Journal of Economic Perspectives, 28, 167-188.

Eichhorst, W., \& Marx, P. (2011). Reforming German Labour Market Institutions. A Dual Path to Flexibility. Journal of European Social Policy, 21, 73-87. 
Elwert, F., \& Winship, C. (2014). Endogeneous Selection Bias: The Problem of Conditioning on a Collider Variable. Annual Review of Sociology, 40, 31-53.

Emmenegger, P. (2014). The Power to Dismiss: Trade Unions and the Regulation of Job Security in Western Europe. Oxford: OUP.

Esping-Andersen, G. (1996). Welfare States without Work: the Impasse of Labour Shedding and Familialism in Continental European Social Policy. In G. Esping-Andersen (Ed.), Welfare States in Transition: National Adaptations in Global Economies (pp. 66-87). London: Sage.

Fischer, G., Janik, F., Müller, D., \& Schmucker, A. (2009). The IAB Establishment Panel: Things Users Should Know. Schmollers Jahrbuch, 129, 133-148.

Fitzenberger, B. Osikominu, A. \& Völter, R. (2006). Imputation rules to improve the education variable in the IAB employment subsample. Schmollers Jahrbuch, 126, 405-436.

Flecker, J. (2009). Outsourcing, Spatial Relocation and the Fragmentation of Employment. Competition and Change, 13, 251-266.

Fligstein, N. (1990). The Transformation of Corporate Control. Cambridge: HUP.

Gangl, M. (2013). Partial Identification and Sensitivity Analysis. In S. Morgan (Ed.), Handbook of Causal Analysis for Social Research (pp. 377-402). Dordrecht: Springer.

Gebel, M. (2009). Fixed-Term Contracts at Labour Market Entry in West Germany: Implications for Job Search and First Job Quality. European Sociological Review, 25, 661-675.

Gebel, M., \& Giesecke, J. (2011). Labor Market Flexibility and Inequality: The Changing SkillBased Temporary Employment and Unemployment Risks in Europe. Social Forces, 90, 1740.

Giesecke, J. (2009). Socio-Economic Risks of Atypical Employment Relationships: Evidence from the German Labour Market. European Sociological Review, 25, 629-646.

Giesecke, J., \& Groß, M. (2003). Temporary Employment: Chance or Risk? European Sociological Review, 19, 161-177.

Goldschmidt, D., \& Schmieder, J. (2017). The Rise of Domestic Outsourcing and the Evolution of the German Wage Structure. The Quarterly Journal of Economics 132: 1165-1217.

Groß, M. (2012). Individuelle Qualifikation, berufliche Schließung oder betriebliche Lohnpolitik was steht hinter dem Anstieg der Lohnungleichheit? Kölner Zeitschrift für Soziologie und Sozialpsychologie, 64, 455-478.

Gundert, S., \& Hohendanner, C. (2014). Do fixed-term and temporary agency workers feel socially excluded? Labour market integration and social well-being in Germany. Acta Sociologica, $57,135-152$.

Hassel, A. (2014). The Paradox of Liberalization - Understanding Dualism and the Recovery of the German Political Economy. British Journal of Industrial Relations, 52, 57-81.

Heining, J., Klosterhuber, W., \& Seth, S. (2014). An Overview on the Linked Employer-Employee Data of the Institute of Employment Research (IAB). Schmollers Jahrbuch, 134, 141-148.

Hertwig, M., Kirsch, J., \& Wirth, C. (2015). Werkverträge im Betrieb. Eine empirische Untersuchung. Düsseldorf: Hans-Böckler-Stiftung.

Hohendanner, C. (2011). Ein-Euro-Jobs und reguläre Beschäftigung. Eine Analyse potenzieller Substitutionseffekte mit Daten des IAB-Betriebspanels. Jahrbücher für Nationalökonomie und Statistik, 231, 210-246.

Holst, H. (2008). The Political Economy of Trade Union Strategies in Austria and Germany: The Case of Call Centres. European Journal of Industrial Relations, 14, 25-45.

Holst, H. (2014). 'Commodifying institutions': vertical disintegration and institutional change in German labour relations. Work, Employment \& Society, 28, 3-20.

Holst, H., Aust, A., \& Pernicka, S. (2008). Kollektive Interessenvertretung im strategischen Dilemma. Atypisch Beschäftigte und die 'dreifache Krise' der Gewerkschaften. Zeitschrift für Soziologie, 37, 158-178. 
Kalleberg, A. (2011). Good Jobs, Bad Jobs: The Rise of Polarized and Precarious Employment Systems in the United States, 1970s to 2000s. New York: RSF.

Kocka, J. (1981). Die Angestellten in der deutschen Geschichte. 1850-1980. Vom Privatbeamten zum angestellten Arbeitnehmer. Göttingen: Vandenhoeck \& Ruprecht.

Layard, R., Nickell, S., \& Jackman, R. (2005). Unemployment: Macroeconomic Performance and the Labour Market. Oxford: OUP.

Lindbeck, A., \& Snower, D. (1986). Wage Setting, Unemployment, and Insider-Outsider Relations. American Economic Review, 76, 235-239.

Maertz, C., Wiley, J., LeRouge, C., \& Campion, M. (2010). Downsizing Effects on Survivors: Layoffs, Offshoring, and Outsourcing. Industrial Relations, 49, 275-285.

Marx, P. (2014). The effect of job insecurity and employability on preferences for redistribution in Western Europe. Journal of European Social Policy, 24, 351-366.

Morgan, S., \& Tang, Z. (2007). Social class and worker's rent, 1983-2001. Research in Social Stratification and Mobility, 25, 273-293.

Müller, S. G., \& Müller, M. (2000). Outsourcing: Analyse und Handlungsempfehlungen. Düsseldorf: Hans-Böckler-Stiftung.

Ochsenfeld, F. (2017). Mercantilist dualization: the introduction of the euro, redistribution of industry rents, and wage inequality in Germany, 1993-2008. Socio-Economic Review, doi: 10.1093/ser/mwx026.

Ochsenfeld, F. (2018). Replication Data for 'The Relational Nature of Employment Dualization: Evidence from Subcontracting Establishments'. https://doi.org/10.7910/DVN/9SEHIQ, Harvard Dataverse, V2.

Ohlert, C. (2016). Establishment Heterogeneity, Rent Sharing and the Rise of Wage Inequality in Germany. International Journal of Manpower, 37, 210-228.

Ordine, P., Rose, G., \& Vella, G. (2017). The Effect of Temporary Agency Workers on Wage of Permanent Employees: Evidence from Linked Employer-Employee Data. Labour, doi:10.1111/labr.12102

Palier, B., \& Thelen, K. (2010). Institutionalizing Dualism. Complementarities and Change in France and Germany. Politics \& Society, 38, 119-148.

Pedulla, D. (2013). The Hidden Costs of Contingency: Employers' Use of Contingent Workers and Standard Employees' Outcomes. Social Forces, 92, 691-722.

Piore, M., \& Sabel, C. (1984). The Second Industrial Divide. Possibilities for Prosperity. New York: Basic Books.

Polavieja, J. (2003). Temporary Contracts and Labour Market Segmentation in Spain: An Employment-Rent Approach. European Sociological Review, 19, 501-517.

Promberger, M. (2012). Topographie der Leiharbeit: Flexibilität und Prekarität einer atypischen Beschäftigungsform. Berlin: edition sigma.

Rehder, B. (2003). Betriebliche Bündnisse für Arbeit in Deutschland. Frankfurt am Main: Campus.

Ridgeway, C. (1997). Interaction and the Conservation of Gender Inequality: Considering Employment. American Sociological Review, 62, 218-235.

Robins, J., Hernán, M., \& Brumback, B. (2000). Marginal Structural Models and Causal Inference in Epidemiology. Epidemiology, 11, 550-560.

Roscigno, V. (2011). Power, Revisited. Social Forces, 90, 349-374.

Rueda, D. (2005). Insider-Outsider Politics in Industrialized Democracies: The Challenge to Social Democratic Parties. American Political Science Review, 99, 61-74.

Schank, T., Schnabel, C., \& Wagner, J. (2007). Do exporters really pay higher wages? First evidence from German linked employer-employee data. Journal of International Economics, 72, 52-74. 
Sørensen, A. (1996). The Structural Basis of Social Inequality. American Journal of Sociology, 101, 1333-1365.

Sørensen, A. (2000). Toward a Sounder Basis for Class Analysis. American Journal of Sociology, 105, 1523-1558.

Solow, R. (1985). Insiders and Outsiders in Wage Determination. The Scandinavian Journal of Economics, 87, 411-428.

Streeck, W. (2009). Re-Forming Capitalism. Institutional Change in the German Political Economy. Oxford: OUP.

Tamer, E. (2010). Partial Identification in Econometrics. Annual Review of Economics, 2, 167195.

Thelen, K. (2004). How Institutions Evolve. The Political Economy of Skills in Germany, Britain, the United States, and Japan. Cambridge: CUP.

Thelen, K. (2014). Varieties of Liberalization and the New Politics of Social Solidarity. Cambridge: CUP.

Tomaskovic-Devey, D. (2014). The Relational Generation of Workplace Inequalities. Social Currents, 1, 51-73.

Tomaskovic-Devey, D., Jacobebbinghaus, P., \& Melzer, S. (2016). The Organizational Production of Earnings Inequalities in Germany, 1994-2010. Available at SSRN: https://ssrn.com/abstract=2879165

Wagner, B., \& Hassel, A. (2016). Posting, subcontracting and low-wage employment in the German meat industry. Transfer, 22, 163-178.

Weeden, K., \& Grusky, D. (2014). Inequality and Market Failure. American Behavioral Scientist, 58, 473-491.

Weil, D. (2014). The Fissured Workplace. Why Work Became So Bad for So Many and What Can Be Done to Improve It. Cambridge: HUP.

Young, C., \& Holsteen, K. (2017). Model Uncertainty and Robustness. A Computational Framework for Multimodel Analysis. Sociological Methods \& Research, 46, 3-40. 


\section{Appendix}

Table A1: Description of variables in establishment-level regression

\begin{tabular}{ll}
\hline Variable & Description \\
\hline $\begin{array}{l}\text { Outcome variable } \\
\text { Rent }\end{array}$ & $\begin{array}{l}\text { Average wage residual of core workers in a given } \\
\text { establishment and a given year, derived from employee- } \\
\text { level wage regression. }\end{array}$ \\
$\begin{array}{l}\text { Treatment variables } \\
\text { Percent temporary }\end{array}$ & $\begin{array}{l}\text { Total number of temporary agency workers divided by total } \\
\text { number of employees. Variable top coded at } 100 \text { percent. }\end{array}$ \\
Percent freelancers & $\begin{array}{l}\text { Total number of freelance workers divided by total number } \\
\text { of employees. Variable top coded at } 100 \text { percent. } \\
\text { Dutsourcing }\end{array}$ \\
$\begin{array}{l}\text { Dummy variable that indicates whether an establishment } \\
\text { has outsourced or closed an entire business unit since the } \\
\text { first year in the observation period. }\end{array}$
\end{tabular}

Control variables

Business volume

Four dummy variables. "Which development do you expect for the current year relative to the previous year? Will business volume..." "remain rather constant" "rather increase" "rather decrease" "do not know yet"

Earnings situation

Dummy variables for 5-point Likert scale. "How was the earnings situation of your establishment in the past business year?" "insufficient", "(just) sufficient", "satisfactory", "good", "very good".

Vacancies

Dummy variable "Are you currently searching for employees (not apprentices) to be hired immediately - so for the next possible date of hiring?".

Export intensity

Variable coded from items "How do your sales distribute across the following regions? (percentage of sales)" "Countries of the European Currency Union (without Germany): Belgium, Finland, France, Greece, Ireland, Italy, Luxemburg, Netherlands, Austria, Portugal, Spain" "The new EU members: Estonia, Latvia, Lithuania, Malta, Poland, Slovakia, Slovenia, Czech Republic, Hungary, Cyprus" "Other foreign countries".

Number of employees Variable "Total number of employees" includes both standard and non-standard forms of employment. Recoded to time-constant categorical variable (establishment mode) for interactions with treatment variables.

Collective bargaining Dummy variable "Does a sectoral collective agreement apply for this establishment?". 
Works council

Dummy variable "In your establishment, is there a works council elected according to the Works Council Constitution Act?". Used only for interaction with the treatment variables. For the vast majority of establishments, works council status is time-constant. For the very few establishment with variation, I recoded the variable to the mode for the given establishment to avoid problems that result from interacting two time-varying variables in fixed effects models.

Industry-size-year (fixed Unique combinations of the industry variable (Klassifikation effects) der Wirtschaftszweige 1993, 2-digit) and the time-constant variable total number of employees (establishment mode, coded into seven categories "less than 9" "10 to 19" "20 to 49 " "50 to 99 " "100 to 249 " "250 to 499 " "500 and more").

State-year (fixed Unique combinations of German federal states and year. effects) 
Table A2: Description of variables in employee-level regression

\begin{tabular}{|c|c|}
\hline Variable & Description \\
\hline \multicolumn{2}{|l|}{ Outcome variable } \\
\hline Wage & $\begin{array}{l}\text { Gross real daily wage in Euros. Values above the social } \\
\text { security contribution ceiling are imputed by Tobit } \\
\text { regressions, fit separately for Eastern and Western } \\
\text { Germany and for each year, and are again top coded at } \\
\text { three times the contribution ceiling. Predictors in the Tobit } \\
\text { regressions are: federal state, number of full-time } \\
\text { employees in the establishment (logged), average wage } \\
\text { (logged), proportion of observations censored, profit } \\
\text { situation, employee age (squared and cubed), gender, fully } \\
\text { interacted with experience (squared and cubed), education, } \\
\text { fully interacted with experience (squared and cubed), } \\
\text { nationality and industry. }\end{array}$ \\
\hline \multicolumn{2}{|l|}{ Control variables } \\
\hline Worker type & $\begin{array}{l}\text { Dummy variables "unskilled worker" "skilled blue collar" } \\
\text { "white collar" }\end{array}$ \\
\hline $\begin{array}{l}\text { Firm-specific } \\
\text { experience }\end{array}$ & Tenure in current establishment, in years. \\
\hline $\begin{array}{l}\text { General potential } \\
\text { experience }\end{array}$ & $\begin{array}{l}\text { Variable coded from current age, year, and highest } \\
\text { education obtained. }\end{array}$ \\
\hline Gender & $\begin{array}{l}\text { Time-constant dummy variable "female", used only for } \\
\text { interaction with experience. }\end{array}$ \\
\hline Vocational training & $\begin{array}{l}\text { Dummy variable (reference: no vocational training), used } \\
\text { only for interaction with experience. }\end{array}$ \\
\hline Spell (fixed effects) & Unique combinations of person and establishment. \\
\hline $\begin{array}{l}\text { Skill cell-year (fixed } \\
\text { effects) }\end{array}$ & $\begin{array}{l}\text { Unique combinations of variables year, occupation (KldB } \\
\text { 1988, 2-digit) and education ("no vocational training" } \\
\text { "vocational training"). }\end{array}$ \\
\hline $\begin{array}{l}\text { State-year (fixed } \\
\text { effects) }\end{array}$ & Unique combinations of 16 German federal states and year. \\
\hline
\end{tabular}


Table A3: Descriptive statistics for establishment characteristics, 2002 and 2008, for capital intensive and other industries.

\begin{tabular}{|c|c|c|c|c|c|c|c|c|}
\hline & \multicolumn{4}{|c|}{ Manufacturing, mining, utilities } & \multicolumn{4}{|c|}{ Other industries } \\
\hline & \multicolumn{2}{|c|}{2002} & \multicolumn{2}{|c|}{2008} & \multicolumn{2}{|c|}{2002} & \multicolumn{2}{|c|}{2008} \\
\hline & mean & s.e. & mean & s.e. & mean & s.e. & mean & s.e. \\
\hline Agency workers (percent of total workforce) & 1.3 & .40 & 2.2 & .22 & .5 & .11 & .8 & .14 \\
\hline Freelancers (percent of total workforce) & .462 & .1808 & .581 & .1599 & .598 & .1384 & .990 & .1611 \\
\hline Outsourcing (occurrence in current year) $[0 ; 1]$ & .037 & .0082 & .009 & .0021 & .027 & .0040 & .017 & .0040 \\
\hline Exports (percentage of sales) & 10.5 & .82 & 11.6 & .91 & 2.4 & .30 & 3.3 & .42 \\
\hline \multicolumn{9}{|l|}{ Earnings situation [0;4] } \\
\hline Insufficient & .147 & .0168 & .070 & .0105 & .122 & .0101 & .073 & .0078 \\
\hline (Just) sufficient & .224 & .0187 & .157 & .0160 & .202 & .0122 & .168 & .0120 \\
\hline Satisfactory & .365 & .0217 & .344 & .0218 & .367 & .0156 & .387 & .0153 \\
\hline Good & .220 & .0161 & .370 & .0211 & .265 & .0142 & .321 & .0140 \\
\hline Very good & .044 & .0092 & .058 & .0078 & .044 & .0067 & .051 & .0064 \\
\hline \multicolumn{9}{|l|}{ Business volume } \\
\hline Same as previous year & .400 & .0211 & .503 & .0221 & .476 & .0160 & .551 & .0154 \\
\hline More than previous year & .158 & .0165 & .231 & .0185 & .135 & .0097 & .207 & .0122 \\
\hline Less than previous year & .369 & .0218 & .148 & .0144 & .337 & .0151 & .177 & .0120 \\
\hline Don't know & .073 & .0121 & .119 & .0179 & .053 & .0066 & .066 & .0086 \\
\hline Establishment looking to fill vacancies $[0 ; 1]$ & .184 & .0155 & .221 & .0160 & .135 & .0103 & .185 & .0110 \\
\hline Covered by industry-level collective bargaining $[0 ; 1]$ & .503 & .0221 & .373 & .0212 & .557 & .0158 & .447 & .0153 \\
\hline Works council $[0 ; 1]$ & .254 & .0145 & .222 & .0145 & .167 & .0098 & .145 & .0084 \\
\hline Eastern Germany [0;1] & .222 & .0137 & .253 & .0145 & .211 & .0101 & .222 & .0105 \\
\hline No. of employees (total) & 67.1 & 2.96 & 65.7 & 3.01 & 33.5 & .94 & 34.5 & .94 \\
\hline $\mathrm{N}=$ & \multicolumn{2}{|c|}{2,397} & \multicolumn{2}{|c|}{2,307} & \multicolumn{2}{|c|}{2,928} & \multicolumn{2}{|c|}{3,036} \\
\hline
\end{tabular}

Source: IAB Establishment Panel; private sector, for-profit establishments. Note: Design-weighted estimates 
Table A4: Descriptive statistics for employee characteristics, 2002 and 2008, for capital intensive and other industries.

\begin{tabular}{|c|c|c|c|c|c|c|c|c|}
\hline & \multicolumn{4}{|c|}{ Manufacturing, mining, utilities } & \multicolumn{4}{|c|}{ Other industries } \\
\hline & \multicolumn{2}{|c|}{2002} & \multicolumn{2}{|c|}{2008} & \multicolumn{2}{|c|}{2002} & \multicolumn{2}{|c|}{2008} \\
\hline & mean & s.e. & mean & s.e. & mean & s.e. & mean & s.e. \\
\hline Wage (€/day) & 106.74 & .122 & 105.70 & .140 & 96.25 & .194 & 91.71 & .198 \\
\hline Female & .21 & .001 & .20 & .002 & .33 & .003 & .33 & .003 \\
\hline Age (years) & 42.10 & .035 & 43.56 & .037 & 41.37 & .057 & 43.16 & .058 \\
\hline Firm-spec. experience (years) & 11.70 & .025 & 13.58 & .029 & 9.79 & .037 & 11.24 & .041 \\
\hline General experience (years) & 24.59 & .036 & 25.88 & .038 & 23.46 & .058 & 25.13 & .059 \\
\hline \multicolumn{9}{|l|}{ Education } \\
\hline No vocational training & .21 & .001 & .17 & .001 & .12 & .002 & .11 & .002 \\
\hline Vocational training & .79 & .001 & .83 & .001 & .88 & .002 & .89 & .002 \\
\hline \multicolumn{9}{|l|}{ Worker type } \\
\hline Unskilled blue collar & .31 & .001 & .31 & .002 & .15 & .002 & .16 & .002 \\
\hline Skilled blue collar & .41 & .002 & .43 & .002 & .33 & .003 & .30 & .003 \\
\hline White collar & .28 & .002 & .26 & .002 & .53 & .003 & .53 & .003 \\
\hline $\mathrm{N}=$ & \multicolumn{2}{|c|}{472,341} & \multicolumn{2}{|c|}{424,762} & \multicolumn{2}{|c|}{215,070} & \multicolumn{2}{|c|}{188,469} \\
\hline
\end{tabular}

Source: LIAB, full-time social insurance covered non-apprentice employees in private sector, for-profit establishments. Note: Design-weighted estimates. 
Table A5: Descriptive statistics of within-establishment variation, for capital intensive and other industries.

\begin{tabular}{|c|c|c|c|c|}
\hline & \multicolumn{2}{|c|}{$\begin{array}{l}\text { Manufacturing, mining, } \\
\text { utilities }\end{array}$} & \multicolumn{2}{|c|}{ Other industries } \\
\hline & $\begin{array}{r}\text { Mean } \\
\text { standard } \\
\text { deviation }\end{array}$ & s.e. & $\begin{array}{r}\text { Mean } \\
\text { standard } \\
\text { deviation }\end{array}$ & s.e. \\
\hline Establishment rents (logged) & .0235173 & .0001995 & .0230527 & .0001496 \\
\hline Percent agency workers & 2.449599 & .0435163 & .8287451 & .0206925 \\
\hline Percent freelancers & .5904479 & .0266384 & .7112550 & .0260739 \\
\hline Outsourcing & .0771738 & .0033147 & .0557805 & .0015785 \\
\hline Exports (percentage of sales) & 6.501494 & .1099045 & 1.670899 & .0466320 \\
\hline Earnings situation $[0 ; 4]$ & .7100693 & .0056978 & .6601146 & .0038874 \\
\hline No. of employees, logged & .0885182 & .0011430 & .1040625 & .0009111 \\
\hline Vacancies & .2989247 & .0036341 & .2341181 & .0023358 \\
\hline Collective bargaining & .1058496 & .0022851 & .1318334 & .0019595 \\
\hline $\mathrm{N}$ (establishments) $=$ & & & & \\
\hline
\end{tabular}

Source: LIAB 2002-2008, private sector, for-profit establishments. Note: Design- and size-weighted estimates, panel-robust standard errors. 
Table A6: Establishment-level regressions on rent, parameters from three-way fixed effects models, specification with all time-varying covariates.

\begin{tabular}{|c|c|c|c|c|}
\hline & \multicolumn{2}{|c|}{$\begin{array}{l}\text { Manufacturing, mining, } \\
\text { utilities }\end{array}$} & \multicolumn{2}{|c|}{ Other industries } \\
\hline & Coef. & s.e. & Coef. & s.e. \\
\hline Percent agency workers & .0011009 & .0001819 & .000748 & .000177 \\
\hline Percent agency workers, squared & -.0000100 & .0000024 & -.000010 & .000002 \\
\hline Percent freelancers & .0000322 & .0004716 & -.000357 & .000186 \\
\hline Percent freelancers, squared & -.0000003 & .0000045 & .000004 & .000002 \\
\hline Outsourcing & .0076449 & .0025637 & .003044 & .002054 \\
\hline Exports (percentage of sales) & .0000507 & .0000342 & .000072 & .000075 \\
\hline \multicolumn{5}{|l|}{ Earnings situation (ref.: satisf.) } \\
\hline Insufficient & -.0086924 & .0015734 & -.005732 & .001340 \\
\hline (Just) sufficient & -.0049761 & .0012231 & -.002514 & .000908 \\
\hline Good & .0027031 & .0012691 & .004298 & .000915 \\
\hline Very Good & .0065336 & .0028228 & .008276 & .001573 \\
\hline \multicolumn{5}{|l|}{ Business situation (ref.: same) } \\
\hline More than previous year & .0023378 & .0008631 & .001727 & .000823 \\
\hline Less than previous year & -.0042943 & .0010798 & -.000286 & .000832 \\
\hline Don't know & .0006392 & .0023721 & -.000346 & .001375 \\
\hline No. of employees & -.0000010 & .0000043 & -.000007 & .000008 \\
\hline No. of employees, squared & $<.0000001$ & $<.0000001$ & $<.000001$ & $<.000001$ \\
\hline No. of employees, logged & .0248514 & .0042534 & .017871 & .002859 \\
\hline Vacancies & .0031543 & .0009547 & .000805 & .000778 \\
\hline Collective bargaining & .0046464 & .0016064 & .002147 & .001194 \\
\hline Establishment fixed effects & \multicolumn{2}{|c|}{ Yes } & \multicolumn{2}{|c|}{ Yes } \\
\hline Industry-size-year fixed effects & \multicolumn{2}{|c|}{ Yes } & \multicolumn{2}{|c|}{ Yes } \\
\hline State-year fixed effects & \multicolumn{2}{|c|}{ Yes } & \multicolumn{2}{|c|}{ Yes } \\
\hline $\mathrm{N}$ (establishment-years) = & \multicolumn{2}{|c|}{18,088} & \multicolumn{2}{|c|}{24,473} \\
\hline
\end{tabular}

Source: LIAB 2002-2008, private sector, for-profit establishments. Note: Design- and size-weighted estimates, panel-robust standard errors. 
Table A7: Establishment-level rent regressions that allow for effect heterogeneity by works council status and establishment size, parameters from three-way fixed effects models; specification with all control variables.

\begin{tabular}{|c|c|c|c|c|}
\hline & \multicolumn{2}{|c|}{$\begin{array}{c}\text { Manufacturing, mining, } \\
\text { utilities }\end{array}$} & \multicolumn{2}{|c|}{ Other industries } \\
\hline & Coef. & s.e. & Coef. & s.e. \\
\hline Percent agency workers & -.000128 & .001063 & .00082 & .00078 \\
\hline Percent agency workers, squared & .000004 & .000015 & -.00002 & .00002 \\
\hline Percent freelancers & -.001470 & .000887 & .00001 & .00031 \\
\hline Percent freelancers, squared & .000013 & .000010 & .00000 & .00000 \\
\hline Outsourcing & -.009804 & .006741 & .02718 & .01372 \\
\hline Percent agency workers $\mathrm{x}$ works council & .001163 & .000310 & -.00072 & .00050 \\
\hline Percent agency wrkrs sq. $x$ wrks council & -.000012 & .000004 & .00001 & .00001 \\
\hline Percent freelancers $x$ works council & .000648 & .000987 & .00053 & .00045 \\
\hline Percent freelancers sq. $x$ works council & -.000003 & .000012 & -.00001 & .00000 \\
\hline Outsourcing $x$ works council & .022973 & .006695 & .00895 & .00455 \\
\hline Exports (percentage of sales) & .000048 & .000035 & .00007 & .00008 \\
\hline \multicolumn{5}{|l|}{ Earnings situation (ref.: satisf.) } \\
\hline Insufficient & -.008686 & .001580 & -.00573 & .00134 \\
\hline (Just) sufficient & -.004996 & .001199 & -.00258 & .00091 \\
\hline Good & .002668 & .001248 & .00425 & .00091 \\
\hline Very Good & .006230 & .002810 & .00810 & .00156 \\
\hline \multicolumn{5}{|l|}{ Business situation (ref.: same) } \\
\hline More than previous year & .002189 & .000868 & .00177 & .00082 \\
\hline Less than previous year & -.004370 & .001068 & -.00032 & .00083 \\
\hline Don't know & .000654 & .002297 & -.00034 & .00138 \\
\hline No. of employees & .000000 & .000004 & -.00001 & .00001 \\
\hline No. of employees, squared & .000000 & .000000 & .00000 & .00000 \\
\hline No. of employees, logged & .024453 & .004172 & .01820 & .00299 \\
\hline Vacancies & .003050 & .000957 & .00083 & .00078 \\
\hline Collective bargaining & .004344 & .001575 & .00214 & .00120 \\
\hline$\%$ agency workers $\times 10-19$ employees & -.000388 & .001280 & -.00036 & .00087 \\
\hline$\%$ agency workers $\times 20-49$ employees & .000148 & .001121 & .00053 & .00090 \\
\hline$\%$ agency workers $\times$ 50-99 employees & .000298 & .001118 & -.00019 & .00094 \\
\hline $\begin{array}{l}\text { \% agency workers } \times 100-249 \\
\text { employees }\end{array}$ & .000257 & .001118 & .00099 & .00091 \\
\hline $\begin{array}{l}\text { \% agency workers } \times \text { 250-499 } \\
\text { employees }\end{array}$ & .000541 & .001138 & .00032 & .00104 \\
\hline$\%$ agency workers $x>500$ employees & .000292 & .001218 & .00175 & .00136 \\
\hline$\%$ agency workers sq. x 10-19 empl. & .000000 & .000023 & .00001 & .00003 \\
\hline$\%$ agency workers sq. x 20-49 empl. & -.000005 & .000015 & .00001 & .00003 \\
\hline \% agency workers sq. x 50-99 empl. & -.000004 & .000015 & .00001 & .00003 \\
\hline$\%$ agency workers sq. x 100-249 empl. & -.000002 & .000015 & -.00001 & .00003 \\
\hline \% agency workers sq. x 250-499 empl. & -.000007 & .000015 & .00001 & .00003 \\
\hline$\%$ agency workers sq. $x>500$ empl. & -.000004 & .000019 & -.00001 & .00003 \\
\hline$\%$ freelancers $\times 10-19$ employees & .004137 & .001076 & -.00044 & .00057 \\
\hline$\%$ freelancers $\times 20-49$ employees & .000560 & .001325 & -.00060 & .00049 \\
\hline$\%$ freelancers x 50-99 employees & .000898 & .001313 & -.00079 & .00071 \\
\hline$\%$ freelancers $\times 100-249$ employees & .001777 & .001155 & -.00103 & .00065 \\
\hline$\%$ freelancers $\times$ 250-499 employees & -.000017 & .001303 & -.00191 & .00094 \\
\hline$\%$ freelancers $x>500$ employees & .000967 & .001295 & -.00171 & .00095 \\
\hline$\%$ freelancers sq. $\times 10-19$ employees & -.000040 & .000012 & .00001 & .00001 \\
\hline$\%$ freelancers sq. $\times 20-49$ employees & -.000008 & .000012 & .00001 & .00001 \\
\hline$\%$ freelancers sq. x 50-99 employees & -.000002 & .000015 & .00001 & .00001 \\
\hline$\%$ freelancers sq. x 100-249 employees & -.000021 & .000011 & .00001 & .00001 \\
\hline$\%$ freelancers sq. $\times$ 250-499 employees & -.000010 & .000012 & .00010 & .00004 \\
\hline$\%$ freelancers sq. $x>500$ employees & -.000015 & .000012 & .00002 & .00001 \\
\hline Outsourcing x 10-19 employees & -.010556 & .014602 & -.03945 & .01619 \\
\hline Outsourcing x 20-49 employees & .001534 & .009773 & -.03039 & .01437 \\
\hline
\end{tabular}




$\begin{array}{lllll}\text { Outsourcing } \times \text { 50-99 employees } & -.017810 & .010640 & -.03147 & .01454 \\ \text { Outsourcing } \times 100-249 \text { employees } & -.009131 & .009351 & -.02754 & .01454 \\ \text { Outsourcing } \times 250-499 \text { employees } & -.004368 & .009403 & -.03429 & .01475 \\ \text { Outsourcing } \times>500 \text { employees } & -.000160 & .009752 & -.02841 & .01501\end{array}$

Industry-size-year fixed effects

State-year fixed effects

Yes

Yes

$\mathrm{N}$ (establishment-years) $=$

Yes

Yes

Yes

Yes

18,088

24,473

Source: LIAB 2002-2008, private sector, for-profit establishments. Note: Design- and size-weighted estimates, panel-robust standard errors. 
Table A8: Employee-level wage regression, parameters from three-way fixed effects models.

\begin{tabular}{|c|c|c|c|c|}
\hline & \multicolumn{2}{|c|}{ Manufacturing, mining, utilities } & \multicolumn{2}{|c|}{ Other industries } \\
\hline & Coef. & s.e. & Coef. & s.e. \\
\hline \multicolumn{5}{|l|}{ Worker type (ref.: unskilled blue collar) } \\
\hline skilled blue collar & .00462 & .00149 & .00520 & .00320 \\
\hline white collar & .05652 & .00267 & .02382 & .00566 \\
\hline Firm-specific experience & .04369 & .00204 & .05053 & .00315 \\
\hline Firm-specific experience, squared & -.00025 & .00002 & -.00030 & .00004 \\
\hline Firm-specific experience, cubed & .0000046 & .0000004 & .0000043 & .0000008 \\
\hline General experience & .01940 & .00259 & .03376 & .00404 \\
\hline General experience, squared & -.00083 & .00004 & -.00105 & .00011 \\
\hline General experience, cubed & .0000074 & .0000005 & .0000094 & .0000013 \\
\hline General experience $\mathrm{x}$ female & -.00794 & .00129 & -.00950 & .00172 \\
\hline General experience sq. $x$ female & .00015 & .00005 & .00024 & .00008 \\
\hline General experience cub. $x$ female & -.000001 & .000001 & -.000003 & .000001 \\
\hline General experience $x$ voc. training & .00152 & .00120 & -.00326 & .00336 \\
\hline General experience sq. $x$ voc. training & -.00009 & .00005 & .00005 & .00011 \\
\hline General experience cub. $x$ voc. training & .0000006 & .0000006 & -.0000005 & .0000013 \\
\hline Spell fixed effects & \multicolumn{2}{|c|}{ Yes } & \multicolumn{2}{|c|}{ Yes } \\
\hline Skill cell-year fixed effects & \multicolumn{2}{|c|}{ Yes } & \multicolumn{2}{|c|}{ Yes } \\
\hline State-year fixed effects & \multicolumn{2}{|c|}{ Yes } & \multicolumn{2}{|c|}{ Yes } \\
\hline $\mathrm{N}$ (employee-years) = & \multicolumn{2}{|c|}{$3,493,787$} & \multicolumn{2}{|c|}{$1,599,230$} \\
\hline
\end{tabular}

Source: LIAB 2002-2008, full-time social insurance covered non-apprentice employees in private sector, for-profit establishments. Note: Design-weighted estimates, panel-robust standard errors. 